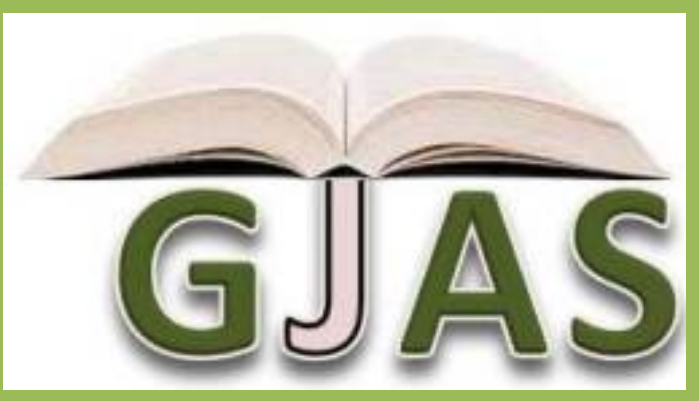

Greener Journal of Agricultural Sciences ISSN: 2276-7770 Impact Factor 2012 (UJRI): 0.7904 ICV 2012: 6.15

Effect of storage temperature and duration on germination of moringa seeds (moringa oleifera)

By

Mubvuma M. T.

Mapanda S.

Mashonjowa E. 


\title{
Effect of storage temperature and duration on germination of moringa seeds (moringa oleifera)
}

\author{
Mubvuma M. T. ${ }^{*}$, Mapanda S. ${ }^{2}$, and Mashonjowa E. ${ }^{3}$ \\ ${ }^{1 *}$ Faculty of Agricultural Science, Department of Soil and Plant Science. Great Zimbabwe University. P.O . Box \\ 1235, Masvingo, Zimbabwe. \\ ${ }^{2}$ Food, Agriculture and Natural Resources Policy Analysis Network (FANRPAN). sipiwemapanda@yahoo.com \\ ${ }^{3}$ Department of Physics, Faculty of Science, University of Zimbabwe P.O. Box MP167, Mount Pleasant, Harare,
} Zimbabwe.

${ }^{1 *}$ Corresponding Author's E-mail: mubvumamagm@yahoo.co.uk, Tel +263-039 252281

\begin{abstract}
Storing moringa seeds soon after harvesting at a specific storage temperature and for specific storage duration may affect the seed quality and germination percentages of the seed. Thus, an experiment was carried out to determine the storage temperature conditions and storage duration that may be used by small holder farmers when storing moringa seed to achieve optimum germination percentages. The results of the study indicated that management of storage temperature and storage duration of seed has potential to improve the seed quality and germination percentage of moringa seed. Across all the treatments, the results suggest that the quality of the seed improves with prolonged storage period up until three months, thereafter the quality of seed decrease with storage time unless stored under low temperatures $\left(10^{\circ} \mathrm{C}\right)$. Good germination results were achieved after storing the seeds at a storage temperature of $25^{\circ} \mathrm{C}$ (ambient temperature) for a duration of 60 days.
\end{abstract}

Keywords: Storage temperature, storage duration, germination percentage, moringa seed.

\section{INTRODUCTION}

Moringa oleifera, also known as Horse radish, benzolive tree, kelor, marango, mlonge, moonga, mulangay, nébéday, saijhan, sajna, Ben oil tree, or drumstick- tree (Fahey, 2005) is one of the world's most useful and nutritious plants (Verdcourt, 1985). The plant belongs to the moringaceae family and is indigenous to Himalayan tracts of India, Bangladesh, Afghanistan and Pakistan (Fahey, 2005). In Zimbabwe, the plant is cultivated in several parts of the country but mainly in the lowveld along Zambezi valley, with the highest concentration being found in Binga district where it is known as Zakaland or Tonga by the locals (Trends, 2005; Maroyi, 2006).

Overwhelming evidence has been found that moringa has high medicinal value (Basara et al., 2011), and is multifunctional (Anwar et al., 2007; Oduro et al., 2008). The plant has high nutritional value (Nambiar, 2006; Thurber and Fahey, 2005), therapeutic uses (Thirusenduraselvi and Jerlin, 2007) and prophylactic properties (Fuglie, 1999; 2000; Fahey, 2005).

Moringa is propagated sexually through seeds and vegetatively through stem cuttings (Fuglie, 1999; Church world Service, 2000). While the stem cutting method is easy and successful for tree propagation, the recent introduction of moringa as a field crop for biomass production requires propagation through seed (Nouman et al., 2012). However, seed viability of the plant is low when compared to other field and horticultural crops (Croft et al., 2012). In particular, germination percentages of moringa seed is not very good soon after harvesting of mature seed (Maroyi, 2006). Although moringa seed does not contain any dormancy, studies on germination percentage of fresh seed is still confusing with some studies reporting better germination percentages from fresh seeds when compared to old seeds, whilst other studies have reported lower germination percentages on fresh seed than on seeds that have been stored for a period of a month up until three months even under different storage conditions (Croft et al., 2012). Germination of seed is a function of duration of storage, storage temperature and moisture content at storage (Croft et al., 2012). Therefore, good management of storage temperature and storage duration may enhance germination of the seed. There is need to investigate and characterise specific storage conditions that are optimal for favourable germination percentages of moringa seed. Such a study should focus on the development of threshold storage temperature and storage duration limits that will allow farmers to have optimum germination percentages. This information is very important, especially to the small holder farmers who normally retain the seed from the previous harvest and use it in the next season. Therefore the major objective of this study was to establish storage temperature and duration threshold limits for optimum germination of moringa seeds. The study was of the hypothesis that germination is highest within the 
first three months of storage, thereafter seed germination can drop with increase in storage duration because of changes in chemical constituents of seed cells which is expected with time. We were also of the hypothesis that optimal germination for moringa is achieved when seeds are stored at relatively lower temperatures $\left(10^{\circ} \mathrm{C}\right)$ which preserves the seed from membrane degradation, decrease in enzyme activity and changes in chemical constituents of seed cells.

\section{Objectives}

\section{Overall Objective}

The broad objective of the study was to improve the seed quality and germination percentages of moringa seed through determining the optimum storage temperature and storage duration requirements that achieves a better germination percentages.

\section{Specific Objectives}

Storing moringa seeds soon after harvesting at a specific storage temperature and for specific storage duration may affect the seed quality and germination percentages of the seed. Now, an experiment was carried out to determine:

- $\quad$ The storage temperature conditions and storage duration that may be used by small holder farmers when storing moringa seed to achieve optimum germination percentages.

\section{MATERIALS AND METHODS}

\section{Study Site}

The experiment was conducted at the Government Seed Testing Laboratory, Seeds Services under the department of Research and Regulatory Services (Zimbabwe).

\section{Experimental Design}

The experiment was a factorial design laid down in a Randomized Complete Block Design with two factors (storage temperature with 3 treatment levels of $10^{\circ} \mathrm{C}, 25^{\circ} \mathrm{C}$, and $35^{\circ} \mathrm{C}$ and storage duration with 5 treatment levels of Zero (0) days, 30 days, 60 days, 90 days and 120 days). Each treatment was replicated 3 times, giving a total of 45 experimental units.

\section{Treatment Development and Allocation}

Soon after harvesting moringa seeds, the seeds were tested for moisture content and stored for 120 days, 90 days, 60 days, 30 days and zero days at different storage temperature conditions of $10^{\circ} \mathrm{C}, 25^{\circ} \mathrm{C}$, and $35^{\circ} \mathrm{C}$ for each storage duration. Each treatment was packed in labelled envelopes of 50 seeds each. Treatment allocation in each plot was randomized by BSTA Statistical package (Basic statistical Analysis System -version 5).

\section{Management of the Experiment}

The experiment was conducted according to the International Seed Testing Association (ISTA, 2005) and Association of Official Seed Analysis (AOSA, 2005). The germination substrate (sand) was first washed under running tape water, before sterilization in an oven at a temperature of $100^{\circ} \mathrm{C}$ to control pathogens. The germinating trays were also sterilized with liquid detergent. During planting of seeds, the seeds were tested for moisture content, before mechanical scarification to increase water up take. The seeds were planted in sand trays at a depth of $2 \mathrm{~cm}$ and in a Walk-in-germination room that had a fluctuating day and night temperature of $20 / 10^{\circ} \mathrm{C}$ respectively. The evaluation of seedlings was conducted on the $7^{\text {th }}$ day and it was the first and final counting. The seedling results were taken from visual observation and were categorized into normal and abnormal seedlings. These normal and abnormal seedlings were then used to calculate the germination percentages. Normal seedlings were defined as the seed that show the potential for continued development into satisfactory plants when sown in good quality soil and under favourable conditions. Abnormal seedlings were defined as that seed which do not show the potential for continued development into satisfactory plants when grown in good quality soil and under favourable conditions. The abnormal seeds category also included damaged seedlings, these were defined as seedlings with weak development or psychological disturbance or in which essential structures are deformed or out of proportion. The data on normal and abnormal seedlings were 
subjected to analysis of variance (ANOVA) using the Statistical Analysis System (SAS, 2000). Mean separation was by Turkey's least significant difference (LSD) at $5 \%$ level.

\section{RESULTS}

\section{Effect of Storage Temperature and Storage Duration on Seed Germination}

The significant $(P<0.05)$ interaction effect of storage temperature and storage duration on germination of moringa seeds is illustrated in table 3.1 below. For moringa seeds that were stored at a low constant temperature of $10^{\circ} \mathrm{C}$, significant differences $(\mathrm{P}<0.05)$ were observed between seeds that were stored for a duration of 30 days and seeds that were stored for a duration of 60,90 and 120 days. Moringa seeds that were stored at a low temperature of $10^{\circ} \mathrm{C}$ showed an increase in germination percentage when their storage duration was increased to 60,90 and 120 days than when the duration was 30 days. For moringa seeds that were stored for a duration of 30 days, significant differences $(P<0.05)$ were observed between seeds that were stored at a temperature conditions of $10^{\circ} \mathrm{C}$ compared with seeds that were stored at either $25^{\circ} \mathrm{C}$ or $35^{\circ} \mathrm{C}$. Moringa seeds that were stored at a temperature of $35{ }^{\circ} \mathrm{C}$ showed no significant differences $(\mathrm{P}<0.05)$ when the storage duration was either 30 days, 60 days or 90 days. No differences were also significant $(P<0.05)$ across all temperature treatments when the storage duration was either 60 days or 90 days. Highest germination percentages were achieved for seeds that were stored at a storage temperature of $25^{\circ} \mathrm{C}$, and for a storage duration of 60 days.

Table 3.1: Effect of Storage Temperature and Storage Duration on Germination of Moringa Seed

\begin{tabular}{|c|c|c|c|c|c|c|}
\hline \begin{tabular}{|l} 
Storage \\
Temperature
\end{tabular} & \begin{tabular}{|l|} 
Moisture \\
Content at \\
planting \%
\end{tabular} & $\begin{array}{l}\text { Storage } \\
\text { Duratio } \\
\text { n }\end{array}$ & \begin{tabular}{|l|} 
Average \\
number of \\
Normal \\
seedlings
\end{tabular} & $\begin{array}{l}\text { Average number } \\
\text { Of Abnormal } \\
\text { Seedlings }\end{array}$ & $\begin{array}{l}\text { Average } \\
\text { number of } \\
\text { dead seed }\end{array}$ & $\begin{array}{l}\text { Germination } \\
\%\end{array}$ \\
\hline Ambient $\left(25^{\circ} \mathrm{C}\right)$ & 8.85 & 30 & $20.33^{\mathrm{a}}$ & 21.6 & 7 & $40.66^{a}$ \\
\hline Ambient $\left(25^{\circ} \mathrm{C}\right)$ & 8.25 & 60 & $41.5^{\mathrm{D}}$ & 5 & 6 & $83.00^{\mathrm{D}}$ \\
\hline $\begin{array}{l}\text { Ambient }\left(25^{\circ} \mathrm{C}\right) \\
\text { Ambient }\left(25^{\circ} \mathrm{C}\right) \\
\text { High }\left(35^{\circ} \mathrm{C}\right)\end{array}$ & $\begin{array}{l}7.91 \\
7.67 \\
8.71\end{array}$ & $\begin{array}{c}90 \\
120 \\
30\end{array}$ & $\begin{array}{l}40.00^{\mathrm{b}} \\
37.5^{\mathrm{b}} \\
38.67^{\mathrm{D}}\end{array}$ & $\begin{array}{c}5 \\
8 \\
5.6\end{array}$ & $\begin{array}{c}4 \\
6 \\
5.6\end{array}$ & $\begin{array}{l}80.00^{\mathrm{b}} \\
75.00 \\
77.34^{\mathrm{b}}\end{array}$ \\
\hline High $\left(35^{\circ} \mathrm{C}\right)$ & 8.18 & 60 & $41.00^{\mathrm{D}}$ & 3.6 & 5.3 & $82.00^{\mathrm{b}}$ \\
\hline $\begin{array}{l}\text { High }\left(35^{\circ} \mathrm{C}\right) \\
\text { High }\left(35^{\circ} \mathrm{C}\right) \\
\text { Low }\left(10^{\circ} \mathrm{C}\right)\end{array}$ & $\begin{array}{r}7.64 \\
7.55 \\
11.05\end{array}$ & $\begin{array}{c}90 \\
120 \\
30\end{array}$ & $\begin{array}{l}39.00^{\mathrm{b}} \\
27.5^{\mathrm{a}} \\
21.67^{\mathrm{a}}\end{array}$ & $\begin{array}{c}6 \\
19.6 \\
18.6\end{array}$ & $\begin{array}{c}5 \\
8 \\
9.6\end{array}$ & $\begin{array}{l}78.00^{\mathrm{b}} \\
55.00^{\mathrm{a}} \\
43.34^{\mathrm{a}}\end{array}$ \\
\hline Low $\left(10^{\circ} \mathrm{C}\right)$ & 11.25 & 60 & $37.67^{\circ}$ & 7.6 & 4.6 & $75.34^{\mathrm{D}}$ \\
\hline $\begin{array}{l}\text { Low }\left(10^{\circ} \mathrm{C}\right) \\
\text { Low }\left(10^{\circ} \mathrm{C}\right)\end{array}$ & $\begin{array}{l}12.65 \\
11.42\end{array}$ & $\begin{array}{c}90 \\
120\end{array}$ & $\begin{array}{c}40.00^{b} \\
41^{b}\end{array}$ & $\begin{array}{l}4 \\
5\end{array}$ & $\begin{array}{l}6 \\
5\end{array}$ & $\begin{array}{l}80.00^{\mathrm{b}} \\
82.00^{\mathrm{b}}\end{array}$ \\
\hline
\end{tabular}

Mean with the same superscripts are not significantly different at $(P<0.05)$.

Lowest germination percentages were observed when the storage temperature was low $\left(10^{\circ} \mathrm{C}\right)$ and with a short storage duration of 30 days, except for seeds that were stored at a temperature of $35^{\circ} \mathrm{C}$ for a duration of 120 days which also recorded lower germination percentages . 


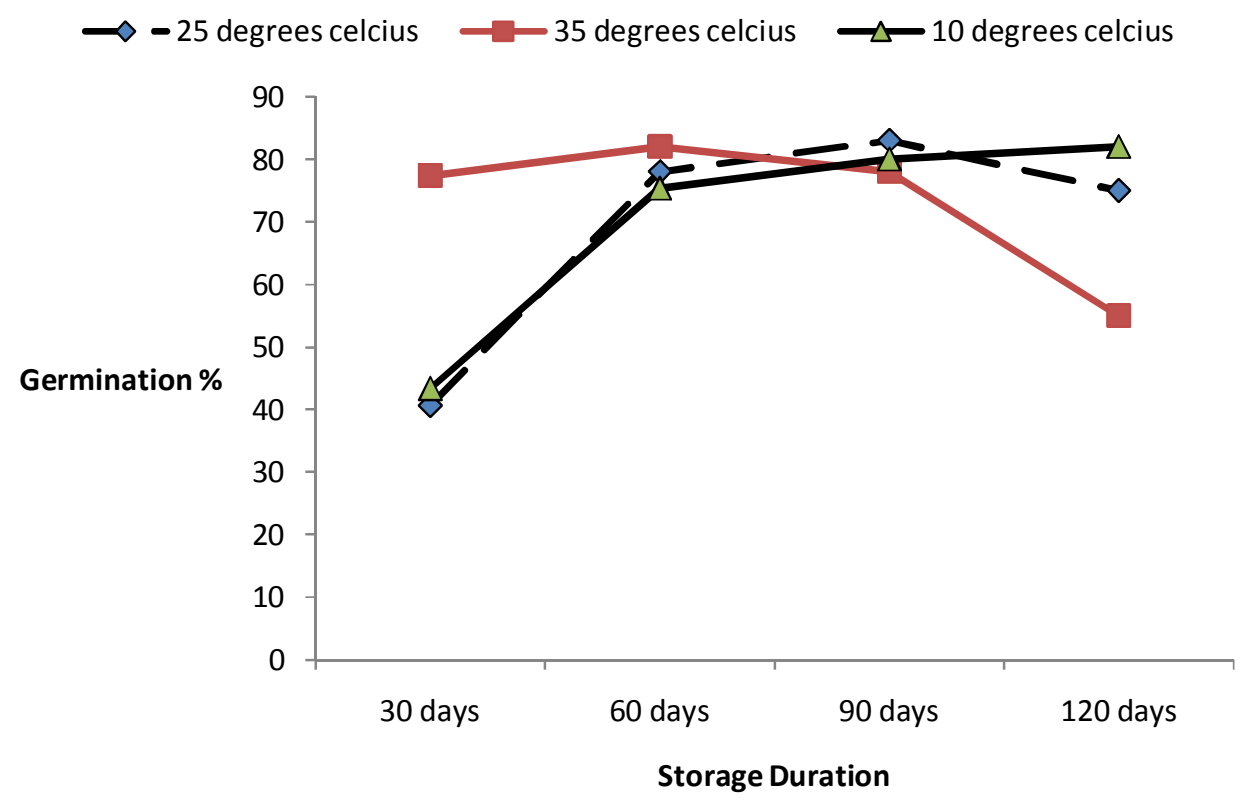

Fig 3.1: Germination performance of moringa seed under different storage temperature and duration.

\section{Effect of Storage Temperature and Duration on Seed Moisture Content}

Storage temperature affected seed moisture content for all the treatments under trial. Seeds that were stored at a low temperature condition of $10^{\circ} \mathrm{C}$ had significantly higher moisture content $(\mathrm{P}<0.05)$ than seeds that were stored at temperature condition of $25^{\circ} \mathrm{C}$ and $35^{\circ} \mathrm{C}$ (Fig 3.2). No differences were significant $(P<0.05)$ in moisture content between seeds that were stored at the same temperature treatment but varying the storage duration. Seeds that were stored at a low temperature $\left(10^{\circ} \mathrm{C}\right)$ showed an increasing trend of moisture content with increase in storage duration and reached a peak value in the 90 days of storage before decreasing in the $120^{\text {th }}$ day of storage. In some cases, the outside cover of the envelopes which contained seeds that were stored at $10^{\circ}$ $\mathrm{C}$ showed few deposition of dew, although the inside of the same envelops appeared dry when viewed using necked eye. However, seeds that were stored at a temperature of $25^{\circ} \mathrm{C}$ and $35^{\circ} \mathrm{C}$ showed a decreasing trend of moisture content with increase in storage duration and their envelopes did not show any sign of deposition of dew. Seed moisture content did not show any effect on germination of the seed.

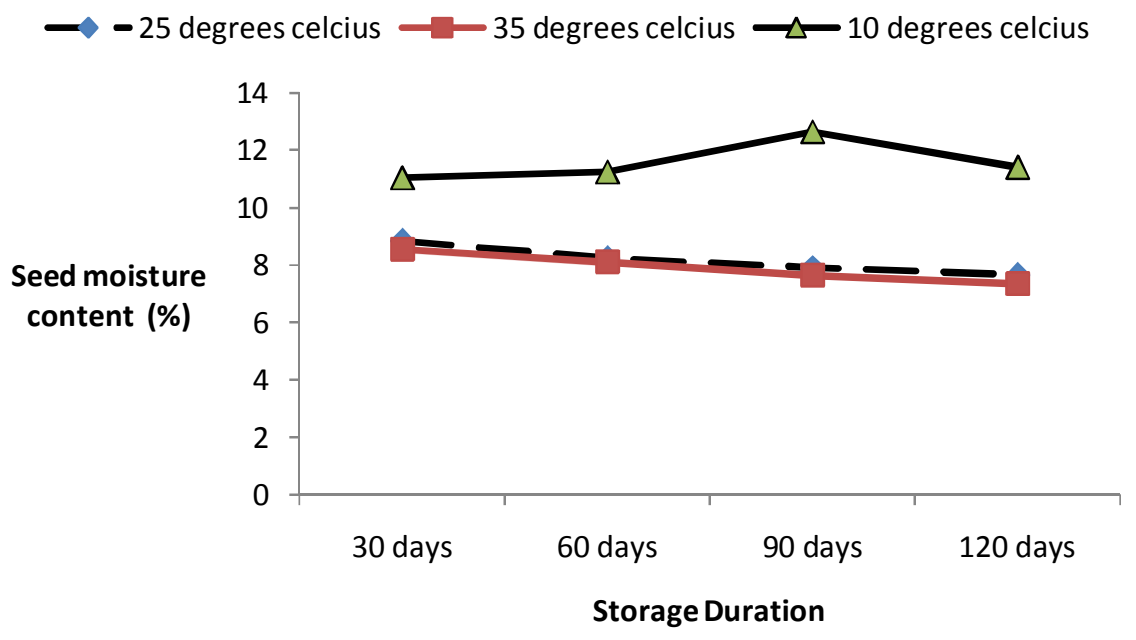

Fig 3.2: Effect of storage temperature and duration on seed moisture content 


\section{DISCUSSION}

The results of the study indicated that management of storage temperature and storage duration of seed has potential to improve the seed quality and germination percentage of moringa seed. Previous studies have recommended the importance of pre-treatment of moringa seed to achieve better germination results (Nouman et al., 2012). The germination percentages from this study compares well with findings by Muhl et al. (2011), and this supports the reliability of the findings. The results also confirmed that moringa does not have any dormancy since the freshly harvested seeds readily germinated after being exposed to the conditions necessary for germination. Across all the treatments, the results suggest that the quality of the seed improves with prolonged storage period up until three months, thereafter the quality of seed deteriorates. This observation compares well with findings by Croft et al. (2012) and is in agreement with our study hypothesis where we expected high germination percentages in the first three months of storage before a decrease in seed quality thereafter. This deterioration in seed quality after three months may be a result of biochemical manifestation (Copeland, 1988), membrane degradation (shaumugavel et al., 1995; Singh and Dadlani, 2003), decrease in enzyme activity (Perl et al., 1978), or changes in chemical constituents of the cell (Verma et al., 2003).

Contrary to one of the study hypothesise where we expected lower temperature $\left(10^{\circ} \mathrm{C}\right)$ storage conditions to maintain better viability of seed and improve the germination percentage over time, the quality of seed also improved when it was stored at high temperatures $\left(35^{\circ} \mathrm{C}\right)$. Even when the seeds were stored for a longer duration (90 days), germination percentages remained high under high temperature conditions before deteriorating after 120 days of storage. This quality improvement may possibly be explained by the genetic adaptation of the seed within the centres of origin and diversity where the ambient temperature ranges between $30^{\circ} \mathrm{C}$ to $35^{\circ} \mathrm{C}$. This high ambient temperature also improves the rate of enzymatic processes within the seed (Vlceshouwers et al., 1995). The existence of no significant difference in germination percentages for seeds that were stored for duration of 60 days and for 90 days across all storage temperature treatments may suggests that there is no need to prolong the storage of the seeds to 90 days since viability would have been achieved with 60 days of storage. However, it is important to take note that viability of the seed may prolong to 90 days before deterioration in quality starts to take place. Highest germination percentages were observed when the storage temperature was either $25^{\circ} \mathrm{C}$ or $35^{\circ} \mathrm{C}$ and the storage duration was 60 days. However storing the seed at $35^{\circ} \mathrm{C}$ may require additional heating equipment in seed storage rooms, especially in countries such as Zimbabwe where the average ambient annual temperature is between $25^{\circ} \mathrm{C}$ and $30^{\circ} \mathrm{C}$. Use of heating equipment will increase storage costs to the farmers and is not relevant in small holder farming setup in developing world. It is therefore suggested that farmers can still achieve good germination results after storing the seeds at a storage temperature of $25^{\circ} \mathrm{C}$ (ambient temperature) for a duration of 60 days. However, for quick planting of seeds which have been harvested soon, the results suggest that the seeds may need to be stored for 30 days at a temperature of $35^{\circ} \mathrm{C}$ to give better germination results.

High moisture content that was observed in seeds that were stored at low temperature of $10^{\circ} \mathrm{C}$ may be a result of condensation process of water vapour which takes place when seed envelop surface temperature was lower than the surrounding air temperature (Sentelhas et al., 2004) The results also showed no effect of seed moisture on germination percentages, and this is expected from seeds that does not contain any dormancy.

\section{CONCLUSION AND RECOMMENDATION}

Storage temperature and storage duration have an interaction effect on the germination percentages of moringa seed. It is recommended that farmers and seed houses may store the seed for a duration of 60 days in the storage room where ambient temperature is averaged at $25{ }^{\circ} \mathrm{C}$ so as to achieve better germination results.

\section{REFERENCES}

Anwar F, Latif S, Ashraf M, Gilani AH (2007). Moringa oleifera: A food plant with multiple medicinal uses. Phytother. Res. 20: 17-25.

Basra SMA, Iftikhar MN, Afzal I (2011). Potential of Moringa (moringa oleifere) Leaf Extract as Priming Agent for hybrid Maize Seeds. International Journal of Agriculture and Biology ISSN 1814-9596.

Church World Service (2000). Moringa oleifera-the miracle tree. Church World Service. Pp3.

Croft M, Bickster A, Manson J, Burnette (2012). Vacuum Sealing vs Refrigeration: Which is the most effective way to store seeds? Echo Asia notes. A Regional Supplement to Echo Development notes. Issue 14, 2012.

Copeland LO (1988). Seed germination. In: Prin. Seed Sci. Tech., Surjeet Publications. Delhi, pp. 55-212.

Fahey JW (2005). Moringa oleifera: A Review of the medical evidence for its Therapeutic, and prophylactic properties. Part 1. Trees for life journal 2005, 1: 5. 
Fuglie LJ (1999). The Miracle Tree: Moringa oleifera: Natural Nutrition for the Tropics. Church World Service, Dakar. 68 pp.; revised in 2001 and published as The Miracle Tree: The Multiple Attributes of Moringa, 172 pp.

Fugile LJ (2000). Moringa oleifera- The Miracle Tree- Church World Services.

Fugile LC (2000). Moringa oleifera- The Miracle Tree- the multiple attribution of Moringa. Darkar, Senegal.

Fuglie LJ (2000). New Uses of Moringa Studied in Nicaragua. ECHO Development Notes \#68, June, 2000. Available from: http://www.echotech.org/

network/modules.php

Fuglie LJ (2001). The Miracle Tree. Moringa oleifera: Natural Nutrition for the Tropics. CWS, Dakar, Senegal. pp115.

Fuglie LJ (2005). The Moringa Tree: a local solution to malnutrition? Church World Service in Senegal. pp75.

ISTA (2005). International Seed Testing Association- International Rules for seed Testing, Seed Science Technology.

Jahn SAA (1998). Using Moringa as coagulants in developing countries, Journal Arwa management operation.

Jahn SA, Musnad HA, Burgstaller H (1986), The tree that purifies water: cultivating multipurpose Moringaceae in the Sudan. Unasylva. 38: 23-28.

Kumur A (1976). Effect of Temperature and substratum on seed germination, India.

Martin D, Price L (2000). The Miracle Tree- Natural Nutrition for the tropics ECHO Technical notes http: /// www. Moringa Tree orga.

Maroyi A (2006). Preliminary check list introduced and naturalized plants in Zimbabwe, kirkia, volume 18.

Muhl QE, Du toil ES, Robbertse PJ (2011). Temperature effect on seed germination and seedling growth of Moringa oleifera Lam. Seed Science and Technology Journal Vol 39, number 1, April 2011, pp 208-213.

Murdoch AJ, Ellis RH (2000). Dormancy, viability and longetivity. In: Fenner, M. (ed.), Seeds. The ecology of regeneration in plant communities. (2nd edition). CABI Publishing, pp. 183-214.

Nambiar VS (2006) Nutritional potential of drumstick leaves: an Indian perspective. In: Moringa and other Highly Nutritious Plant Resources: Strategies, Standards and Markets for a Better Impact on Nutrition in Africa. Accra, Ghana.

Nouman W, Siddiqui MT, Basra SMA, Afzal I, Rehman h (2012). Enhancement of emergence potential and stand establishment of Moringa oleifera Lam. by seed priming. Turk. J. Agric. For. 36: 227-235.

Oduro I, Ellis WO, Owusu D (2008). Nutritional potential of two leafy vegetables: Moringa oleifera and Ipomoea batatas leaves. Scientific Research and Essay. 3(2): 57-60.

Perl M, Luria I, Gelmond H (1978). Biochemical changes in sorghum seeds affected by accelerated ageing. J. Exp. Bot. 29 (109): 479-509.

Sentelhas PC, Gillespie TJ, Gleason ML, Gleason ML, Monteiro JEBA, Helland ST (2004). Operational exposure of leaf wetness sensors. Agric. For. Meteorol. 126: 59-72.

Shanmugavel S, Anuradha Varier, Malavika Dadlani (1995). Physiological attributes associated with seed ageing in soybean (Glycine max (L.) Merrill) cultivars. Seed Res. 23(2): 61-66.

Singh KK, Dadlani M (2003). Effect of packaging on vigor and viability of soybean (Glycine max (I.) Merrill) seed during ambient storage. Seed Res. 31(1): 27-32.

Smith MT (1992). Dormancy and Germination, Durban, South Africa.

Thirusenduraselvi D, Jerlin R (2007). Effect of Pre-germination Treatments on the emergency percentage of Bitter Gourd cv Co1 seeds. Tropical Agricultural Research and Extension 10, 2007.

Thurber MD, Fahey JW (2009). Adoption of Moringa oleifera to combat under-nutrition viewed through the lens of the "Diffusion of Innovations" theory. Ecol Food Nutr. 48: 212-225.

Trends (2005). Moringa, the miracle tree. Harare. Zimbabwe.

Verma SS, Tomer RPS, Urmil Verma (2003). Loss of viability and vigour in Indian mustard seeds stored under Ambient conditions. Seed Res. 31(1): 98-101.

Verdcourt R (1985). A synopsis of the moringacea bull 44.

VIceshouwers LM, Bouwmeester HJ, Karssen CM (1995). Redefining Seed Dormancy: an attempt to integrate physiology and ecology. Journal of Ecology,83: 1031-1037. 